\title{
Macroeconomics and Monetary Policy: Competing Theoretical Frameworks
}

\begin{abstract}
There is widespread agreement that monetary policy matters, but there is disagreement about how it should be conducted. Behind this disagreement lie differences in theoretical understandings. The paper contrasts the New Classical, Neo-Keynesian, and Post Keynesian frameworks, thereby surfacing the differences. The New Classical model has policy only affecting long run inflation. The Neo-Keynesian model has policy impacting inflation, unemployment, and real wages. The Post Keynesian model also impacts growth, so policy implicitly picks a quadruple. Inflation targeting is a sub-optimal policy frame because it biases decisions toward low inflation by obscuring the fact that policy also affects unemployment, real wages, and growth.
\end{abstract}

Key words: monetary policy, inflation targeting, New Classical, Neo-Keynesian, Post Keynesian.

JEL ref.: E1, E12, E13, E50, E52.

Thomas I. Palley

Economics for Democratic \& Open Societies

Washington DC

Mail@thomaspalley.com

Paper prepared for the meetings of the Eastern Economic Association held in New York, NY, February 23 - 25, 2007. 


\section{The Question}

There is widespread agreement that monetary policy critically impacts macroeconomic performance. However, there is significant difference regarding how monetary policy should be framed and conducted.

Behind this difference lie disagreements about the economy. The current paper aims to surface those disagreements and analyzes how different theoretical macroeconomic frameworks give rise to different recommendations for framing and conduct of monetary policy

\section{Framing the optimal monetary policy debate}

The standard approach to optimal monetary policy is in terms of constrained maximization of a social welfare function. That approach is useful and illuminates the critical factors affecting determination of monetary policy. These factors are:

i) The specification of the policymaker's objective function

ii) The structure of the economy;

iii) The instruments of monetary policy (the choice variables);

iv) The nature of uncertainty - target uncertainty, instrument impact uncertainty, and uncertainty about aggregate demand and supply;

v) The distribution of information - which agents know what and when do they know it and get to act.

Together, these factors determine the nature of the monetary authority's constrained maximization program

In many regards, the recent history of monetary economics can be understood as exploring different elements of the monetary authority's constrained maximization 
program. In the early 1970s debate focused on the "instrument choice" question, and whether monetary policy should target the interest rate or money supply. Poole (1970) examined this question within the context of the neo-Keynesian ISLM model. Sargent and Wallace (1975) examined it using a new classical rational expectations (RE) model. Post-Keynesians, with their theory of endogenous money supply (Moore, 1988) have criticized this debate arguing that money supply targeting is infeasible because the money supply is determined by bank lending. That means the monetary authority can only target the interest rate.

The mid-1970s and early 1980s saw a dramatic change in the framing of the optimal monetary policy problem. Lucas (1973) adopted a classical macroeconomic framework with rational expectations (RE), and argued that "fooling" workers about inflation explains why output and employment respond positively to inflation. His work triggered a two-fold shift. First, and most importantly, there was a shift from using Keynesian economics to describe the structure of the economy to using classical macroeconomics. Second, RE shifted attention to issues of the distribution of information about inflation, learning and agents' responses to monetary policy (Lucas, 1976). Thus, the effectiveness and impact of policy could change as agents learned and responded.

Concern with learning and response then directed attention toward time and game theoretic considerations. Kydland and Prescott (1977) introduced the time-consistency problem for monetary policy, while Barro and Gordon (1983) introduced gaming between the monetary and economic agents. These concerns in turn triggered interest in issues of policy credibility, giving rise to the "rules vs. discretion" policy literature (Taylor, 1993). Additionally, these models tacitly smuggled in the assumption that the 
monetary authority's social welfare function was different from the public's welfare function, which contrasts with the Keynesian literature that assumed a benevolent policy maker (Palley, 1996a).

The current paper focuses on descriptions of the structure of the economy and their implications for policy. The structure of the economy represents the "constraints" in the monetary authority's optimization program, and is analogous to the budget constraint in the household's utility maximization program.

The economic structure determines what is feasible, and is therefore a first-order source of difference regarding monetary policy. Rational expectations, the distribution of information, learning, and credibility matter, but they are second-order issues. Unfortunately, the economics profession (including research departments at central banks and the international financial institutions) has chosen to focus on these second-order more technical concerns and has refused engagement on questions of structure.

\section{Economic structure and optimal monetary policy}

The constraints in the monetary authority's optimization program are macroeconomic relations, and behind these macro relations often lies a complicated microeconomics. That is what is meant by the micro-foundations of macroeconomics.

This section develops three competing models describing the macro economy. These models constitute the economic structure that constrains the monetary authority in its choice of monetary policy. The three models focus on inflation, unemployment, income distribution, and growth. Monetary policy potentially affects all. According to the New Classical model, in the long run policy can only affect inflation. According to the Post-Keynesian model, monetary policy can affect inflation, 
unemployment, income distribution, and growth. The Neo-Keynesian model also has policy affecting inflation, unemployment, and real wages, but uses very different economic logic.

\section{III.1 The New Classical model}

New classical (NC) economics now dominates professional thinking about macroeconomics and monetary policy, and understanding policy today requires understanding the $\mathrm{NC}$ model. The model of inflation, unemployment, distribution, and growth is described by the following six equations:

(1) $\pi=f\left(u-u^{*}\right)+\pi^{e} \quad f_{1}<0, f(0)=0$

[SR Phillips Curve]

(2) $w / p=w\left(u-u^{*}, k\right)$ $\mathrm{w}_{1}>0, \mathrm{w}_{2}>0, \mathrm{w}(0 . \mathrm{k})>0[$ Neo-classical wage curve $]$

(3) $\Pi=\Pi(\mathrm{w} / \mathrm{p}, \mathrm{k})$ $\Pi_{1}<0 . \Pi_{2}<0$ [Wage-profit rate frontier]

(4) $g=g^{*}+g\left(\Pi-\Pi^{*}, k-k^{*}\right)$ $\mathrm{g}_{1}>0, \mathrm{~g}_{2}<0, \mathrm{~g}(0,0)=0$ [SR growth rate]

(5) $g^{*}=n+a$ [LR growth rate]

(6) $\Pi^{*}=f^{\prime}\left(k^{*}\right)=n+a+d$ [LR marginal product of capital]

where $\pi=$ inflation rate, $\mathrm{u}=$ unemployment rate, $\mathrm{u}^{*}=$ natural rate of unemployment $(\mathrm{NAIRU}), \pi^{\mathrm{e}}=$ expected inflation, $\mathrm{w} / \mathrm{p}=$ real wage, $\mathrm{k}=$ capital - labor ratio, $\Pi=$ profit rate, $\mathrm{g}^{*}=$ natural growth rate, $\mathrm{n}=$ population growth, $\mathrm{a}=$ rate of technological progress, $\mathrm{d}=$ rate of depreciation, and $\mathrm{f}^{\prime}()=$. marginal product of capital. ${ }^{1}$

Equation (1) is the Phillips curve. Equation (2) is the real wage expressed in unemployment space. ${ }^{2}$ Equation (3) is the wage - profit rate frontier. Equation (4) is the

\footnotetext{
${ }^{1}$ Note that when $\mathrm{k}=\mathrm{k}^{*}$ then $\Pi=\Pi^{*}$ so that $\mathrm{g}(0,0)=0$

${ }^{2}$ The real wage is usually expressed in terms of the marginal product of labor. However, it can readily be expressed in unemployment space by writing the labor market clearing condition as follows: $\left.\mathrm{N}^{\mathrm{d}}(\mathrm{w} / \mathrm{p})=\left[1-\mathrm{q}\left(\pi-\pi^{\mathrm{e}}\right), \mathrm{X}\right)\right] \mathrm{N}^{\mathrm{s}}(\mathrm{w} / \mathrm{p})$ where $\mathrm{N}^{\mathrm{d}}=$ labor demand, $\mathrm{N}^{\mathrm{s}}=$ labor supply, $\mathrm{q}($.$) = proportion of$ workers with frictional unemployment, $\mathrm{X}=$ vector of variables affecting the efficiency of labor market
} 
short run growth function. Equation (5) is the long run steady state rate of growth, and equation (6) is the long run steady state rate of profit. These equations constitute the structure of the economy that constrains monetary policy.

Behind these equations lies a particular microeconomic foundation. The Phillips curve and neo-classical wage curve rest on the work of Friedman (1968), Phelps (1968) and Lucas (1973). The long run growth rate and long run rate of profit derive from Solow's (1956) neo-classical growth model.

The model is illustrated in Figure 1. Monetary policy can be thought of as controlling the rate of inflation via control of the nominal interest rate that determines the rate of nominal demand growth. ${ }^{3}$ Within this framework, unanticipated monetary policy can have short-run impacts on inflation, unemployment, income distribution, and growth. Anticipated monetary policy only affects inflation. In the long run, monetary policy is fully anticipated, so its affects are restricted to inflation.

The logic of the model is as follows. An unanticipated permanent monetary expansion causes a movement up along the short run Phillips curve, raising inflation and lowering unemployment. Unemployment falls because workers misperceive the rise in nominal wages and are fooled into accepting jobs. Frictional unemployment therefore falls, but so does the real wage. The decline in the real wage raises the profit rate, stimulating an investment boom that raises the capital stock and the growth rate. ${ }^{4}$

\footnotetext{
search, $\mathrm{q}(0)>0, \mathrm{q}_{1}<0$ and $\mathrm{q}_{2}>0$. Unexpected increases in inflation give rise to decreased frictional unemployment that increases the labor supply and lowers the real wage. Improved worker job search efficiency $(X)$ has the same effect.

${ }^{3}$ The rate of inflation can be thought of as a funnel through which all demand variables flow. That also includes positive fiscal policy and private sector demand shocks that have the same impact as expansionary monetary policy.

${ }^{4}$ The model can also be used to describe the long run growth dynamics of the economy. Over time, capital accumulation raises the capital labor ratio, shifting up the wage curve and lowering the profit rate function. Until the steady state capital labor ratio is reached.
} 
Thereafter, once workers learn they have been fooled, they return to their original labor supply behavior and unemployment and the real wage both increase. The profit rate then falls and given the prior over-accumulation of capital, there is a cutback in investment and growth rate falls. Eventually, the economy returns to the initial equilibrium but with a higher rate of inflation located on a higher short run Phillips curve. $^{5}$

The model has clear implications for monetary policy. Inflation is a "bad" and inflation does not affect the equilibrium unemployment rate, real wage, or growth rate. Consequently, the policy implication is aim for price stability (zero inflation). Additionally, avoid inflation surprises and inflation variability that fool workers and firms into inefficient labor supply and investment decisions.

If deflation is a problem due to nominal interest rate floors and there is also uncertainty regarding the aggregate demand impact of monetary policy, then monetary policy will want to pick a positive inflation target to protect against unintended deflation (Palley, 2006). This seems to be current central bank thinking in both the United States and Europe, where two percent inflation target has become the policy norm.

\section{III.2 The Neo-Keynesian Model}

Neo-Keynesian macroeconomics dominated economics and policymaking from the 1950s through to the late 1970s. There are two key differences between the neoKeynesian and New Classical models. The first concerns the specification of the Phillips curve, while the second concerns the specification of the long run rate of profit.

\footnotetext{
${ }^{5}$ The process of capital stock adjustment causes the wage curve, wage - profit rate frontier, and short run growth rate function to shift. The expansion of the capital stock raises the real wage for every rate of unemployment. It also shifts down the short run growth function since firms accumulate less capital for any
} 
These two differences generate the following alternative specification:

(7) $\pi=\mathrm{f}(\mathrm{u})+\lambda \pi^{\mathrm{e}} \quad \mathrm{f}_{1}<0,0<\lambda<1$

[SR Phillips Curve]

(8) $\Pi^{*}=f^{\prime}\left(k^{*}\right)=f^{\prime}\left(n+a+d, \pi^{e}\right)$

$\mathrm{f}_{1}<0, \mathrm{f}_{2}<0$

[LR marginal product of capital]

Equation (7) describes the neo-Keynesian Phillips curve in which there is no natural rate of unemployment, and there is a permanent trade-off between higher inflation and lower unemployment. This follows from the coefficient of inflation expectations, $\lambda$, being less than unity. ${ }^{6}$

Equation (8) describes the long run profit rate, and it is now negatively impacted by the expected rate of inflation. The logic is based on Tobin (1965) in which higher expected inflation induces a shift in portfolio demands away from money toward capital. This shift induces increased capital accumulation, raising the steady state capital stock and lowering the steady state marginal product of capital that determines the profit rate.

The logic of the model is readily understandable in terms of Figure 1. In the short run, expansionary monetary policy causes a movement along the Phillips curve that raises inflation and lowers unemployment, and the real wage falls while the profit rate rises. Thereafter, capital stock dynamics kick in as firms raise their desired capital. This causes the neo-classical wage curve to shift up and the wage - profit frontier to rotate counterclockwise. The long run equilibrium is characterized by a lower unemployment rate, a higher real wage, a lower profit rate, and an unchanged steady -state growth rate. These

given profit rate. Over time, the excess capital is depreciated away and the schedules shift back to their original position. These dynamics are described in Lucas (1975).

${ }^{6}$ The problem for neo-Keynesians was that the Phillips curve was always an empirical relation that lacked microeconomic foundations. The excess labor supply and demand micro foundations suggested by Lipsey (1960) are in fact a theory of real rather than nominal wage inflation, and they actually generate a natural rate of unemployment. Tobin's (1972) disequilibrium dynamics theory of the Phillips curve does provide micro-foundations. Unfortunately that approach was not formalized until the 1990s (Palley, 1994; Akerlof et al, 1996) by which time the battle of ideas had been lost, and the economics profession had become captured by new classical macroeconomics. 
long run changes all follow from the increase in the capital - labor ratio caused by inflation's positive impact on the demand for capital.

The implications are that monetary policy can have both short and long run impacts on the unemployment rate; the real wage, income distribution, and the capital labor ratio. The size of these long run affects depends on the magnitude of portfolio substitution between money and capital in response to inflation. However, monetary policy cannot affect the long run growth rate, and its short run impact on the real wages is negative. Finally, what constitutes optimal monetary policy depends critically on the policymaker's preferences with regard to inflation and unemployment.

\section{III.3 The Post Keynesian Model}

The New Classical model has expected monetary policy being neutral in both the short and long runs. Money and inflation are both veils. The neo-Keynesian model allows monetary policy to have real effects in both the short and long runs, so money and inflation are not neutral. Both models share the neo-classical marginal product theory of income distribution, giving them significantly shared micro foundations.

The Post Keynesian model employs fundamentally different microeconomic foundations. Though it arrives at some similar conclusions to the neo-Keynesian model, these conclusion rest on different reasoning that produces very different explanations of how monetary policy impacts the economy

The equations of the Post Keynesian model are as follows:

(9) $\pi=\mathrm{f}\left(\mathrm{u}, \lambda \pi^{\mathrm{e}}\right) \quad \mathrm{f}_{1}<0, \mathrm{f}_{2}>0,0<\lambda<1, \pi=\pi^{\mathrm{e}}$ [Dynamic disequilibrium.Phillips Curve]

(10) $w / p=w(u, k)$

$\mathrm{w}_{1}<0, \mathrm{w}_{2}>0$

[Wage curve]

(11) $\Pi=\Pi(w / p, u, k)$

$$
\Pi_{1}<0, \Pi_{2}<0, \Pi_{3}<0
$$

[Profit rate] 
Equation (9) describes the Phillips curve, which as in the neo-Keynesian model has a long run negative slope that gives rise to a permanent trade-off between inflation and unemployment. The micro foundations explaining this trade-off depend on the type of inflation. In a demand-pull environment, inflation helps grease the wheels of labor market adjustment according to the logic developed by Tobin (1972) in his description of a multi-sector disequilibrium economy that is formalized in Palley (1994). The coefficient $\lambda$ represents the degree of downward real wage resistance in sectors with unemployment. If $\lambda=1$, then there is full resistance and inflation cannot help grease labor market adjustment in depressed sectors since it is fully incorporated into nominal wage settlements.

In a cost-push/conflict inflation environment the slope of the Phillips curve is the result of the sequence of wage and price-setting moves by workers and firms (Myatt, 1986; Palley, 1996b).

Equation (10) describes a conflict wage curve (Blanchflower and Oswald, 1990, 1994) in which the real wage is negative function of the rate of unemployment. In effect, unemployment proxies for wage bargaining power. Real wages determined by bargaining power, rather than the marginal product of labor. However, productivity, the capital stock and technology still matter because they determine the size of the economic cake available for division between labor and capital.

Equation (11) describes the profit rate function. The profit rate is negatively impacted by the real wage, reflecting the cost effect of higher wages. It is also negatively impacted by unemployment, so that higher unemployment lowers the profit rate. This 
channel can be thought of as the Keynesian demand channel, with higher unemployment rates being associated with lower demand and utilization that lowers profitability. Substituting equation (10) into (11) yield

$\left(11^{\prime}\right) \Pi=\Pi(\mathrm{w} / \mathrm{p}(\mathrm{u}, \mathrm{k}), \mathrm{u}, \mathrm{k})$

Differentiating with respect to $u$ then yields

$\delta \Pi / \delta \mathrm{u}=\Pi_{\mathrm{w} / \mathrm{p}} \mathrm{w} / \mathrm{p}_{\mathrm{u}}+\Pi_{\mathrm{u}}{ }^{>}<0$

This shows the slope of the profit rate function is ambiguous, reflecting a conflict between cost and demand effects. ${ }^{7}$ This feature is discussed further below.

Lastly, equation (12) describes the growth rate function in which growth depends positively on the profit rate and negatively on the unemployment rate. The latter effect proxies for the adverse impact of weak demand conditions. Substituting equation (11') into (12) yields

(12') $\mathrm{g}=\mathrm{g}(\Pi(\mathrm{w} / \mathrm{p}(\mathrm{u}, \mathrm{k}), \mathrm{u}, \mathrm{k}), \mathrm{u})$

Differentiating with respect to unemployment then yields

$\delta \mathrm{g} / \delta \mathrm{u}=\mathrm{g}_{\Pi}\left[\Pi_{\mathrm{w} / \mathrm{p}} \mathrm{w} / \mathrm{p}_{\mathrm{u}}+\Pi_{\mathrm{u}}\right]+\mathrm{gu}_{\mathrm{u}}>0$

The slope of the growth rate function in unemployment space is also ambiguous owing to opposing effects of declining unemployment on costs and demand. Growth is endogenous and depends on the strength of aggregate demand, the logic being demand conditions influence investment spending that in turn influences innovation and productivity growth (Palley, 1996c).

The Post Keynesian model is illustrated in Figure 2. The left-hand side panels show the Phillips curve and the wage curve. The right-hand side shows the profit and

\footnotetext{
${ }^{7}$ Palley (1995) presents a model of the business cycle in which output fluctuations are driven by investment fluctuations that in turn rest on the non-linearity of the profit rate function.
} 
growth rate functions. The profit rate is non-linear. Initially the profit rate rises as the unemployment rate falls because demand effects dominate wage (cost) effects. However, at lower unemployment rates cost effects begin to dominate as profit squeeze sets in. The growth rate is also non-linear. At high unemployment rates, decreases in the unemployment rate raise growth as the demand effect dominates the wage cost effect. However, as the unemployment rate continues falling the profit squeeze effect kicks in and lowers growth.

The model has several important implications. First, there is no natural rate of unemployment or natural rate of growth Second, the real wage is pro-cyclical real. Third, growth can be both wage-led and profit-led (Bhaduri and Marglin, 1990). At high unemployment rates there is no growth cost to decreasing unemployment and increasing wages. The shape of the wage curve is a vital factor since it dramatically affects the curvature of the profit and growth rate functions. If the wage curve rises early and sharply, the profit rate and growth rate will tend to peak at a relatively high unemployment rate. This suggests there can be employment and growth benefits to wage restraint, and the challenge is to maintain a "high but flat" wage curve.

The model also has important implications for policy. Unlike the new classical model, monetary policy does not just affect inflation. It also affects the unemployment rate, the real wage, and the profit and growth rates. That is why monetary policy is so critical. At high unemployment rates, the only cost to expansionary policy is increased inflation. However, as the unemployment rate falls there may be a trade-off between higher wages and lower unemployment versus higher inflation and lower growth. That is a potentially ugly situation. 
The shape of the profit and growth rate functions is critical, and they in turn depend importantly on the shape of the wage curve. Those are empirical issues, but it does seem that the wage curve, the profit rate function, and growth rate function are all relatively flat. That implies there is probably little in the way of an unemployment versus growth trade-off.

Finally Akerlof at al. (2000) and Palley $(1998,2003)$ argue that the Phillips curve may be backward bending as shown in Figure 3. In this case, there is a minimum unemployment rate of inflation (MURI). If the wage curve is flat, then policy should be able to reach the MURI. However, if real wages rise steeply as unemployment decreases then there may be a trade-off between growth and unemployment

\section{Implications for the inflation targeting debate}

The above models have important implications for the debate over whether the

Federal Reserve should adopt an explicit inflation targeting regime, a policy that Federal Reserve Chairman Ben Bernanke (Bernanke, 2003; Bernanke et al., 1999, 1997) is known to be a strong advocate of. Thus far, debate has tended to run within the rules versus discretion paradigm, but the above model highlight a deeper problem with the political economy of inflation targeting.

First, the models show that what constitutes an optimal rate of inflation will vary according to the model adopted. Analytically, optimal monetary policy is the solution of the monetary authority's constrained maximization problem. That solution depends on the constraints, which represent the assumed structure of the economy. Different assumed structures result in different policy recommendations.

Second, the models show how the debate over inflation targeting embeds a 
dangerous political economy. In the new classical macro model monetary policy can only affect the long run rate of inflation. However, in the neo-Keynesian and Post Keynesian models monetary policy has long run impacts on the rate of unemployment, the real wage, and the rate of growth. In those models, monetary policy is implicitly picking a quadruple consisting of inflation, unemployment, real wages, and growth.

That has vital public policy implications. Inflation is a "bad". Consequently, framing monetary policy exclusively in terms of inflation (i.e. inflation targeting) will create a dynamic encouraging low and sub-optimal inflation. If the policy choice is posed as two versus three percent inflation, that will tend to encourage selection of a two percent target. The reality is that the monetary authority is picking a quadruple consisting of inflation, unemployment, real wages, and growth. Inflation is therefore only one element of the choice, and it should be presented as such. Under those conditions three percent inflation may be preferred to two percent inflation if it generates a lower unemployment rate, a higher real wage, and faster growth. That speaks against inflation targeting as the frame for public discourse of monetary policy (Palley, 2006). 


\section{References}

Akerlof, G.A., Dickens, W.T., and Perry, G.L., "Near-Rational Wage and Price Setting and the Long Run Phillips Curve," Brookings Papers on Economic Activity, 1 (2000), 1 -60 .

Inflation," Brookings Papers on Economic Activity, 1 (1996), 1 -76.

Barro, R.J. and D.B. Gordon, "A Positive Theory of Monetary Policy in a Natural Rate Model,” Journal of Political Economy, 91 (1983), 589 - 610.

Bernanke, B.S., "A Perspective on Inflation Targeting," Remarks at the annual Washington Conference of the National Association of Business Economists, Washington, DC, March 25, 2003.

Bernanke, B.S., T. Laubach, F.S. Mishkin, and A.S. Posen, Inflation Targeting: Lessons from the International Experience, Princeton: Princeton University Press, 1999.

Bernanke, B.S., and F.S.Mishkin, "Inflation targeting: A New Framework for Monetary Policy?" Journal of Economic Perspectives, 11 (2) (Spring 1997), 97 - 116.

Bhaduri, A., and Marglin, S., "Unemployment and the Real Wage: the Economic Basis of Contesting Political Ideologies," Cambridge Journal of Economics, 14 (1990), 375 - 95.

Blanchflower, D.G., and Oswald, A.J., "The Wage Curve," Scandinavian Journal of Economics, 92 (1990), 215-35.

, The Wage Curve, Cambridge: MIT Press, 1994.

Friedman, M., "The Role of Monetary Policy,” American Economic Review, 58 (1968), $1-17$.

Kydland, F.E., and E.C. Prescott, "Rules Rather than Discretion: The Inconsistency of Optimal Plans," Journal of Political Economy, 85 (1977), 473 - 92.

Lipsey, R.G., "The Relation Between Unemployment and the rate of Change of Money Wage Rates in the United Kingdom, 1862 - 1957; A Further Analysis," Economica, 27 (1960), 1 - 31.

Lucas, R.E., Jr., "Econometric Policy Evaluation: A Critique,” Journal of Monetary Economics, 2 (September 1976), 19 - 46.

---------, “An Equilibrium Model of the Business Cycle,” Journal of Political Economy, 83 (1975), $1113-1144$. 
--------, “Some International Evidence on Output - Inflation Trade-offs,” American Economic Review, LXIII (1973), 326 - 34.

Moore, B.J., Horizontalists and Verticalists: the Macroeconomics of Credit Money, Cambridge: Cambridge University Press, 1988.

Myatt, A., "On the Non-Existence of the Natural rate of Unemployment and Kaleckian Underpinnings to the Phillips Curve," Journal of Post Keynesian Economics, 8 (Spring 1986), $447-62$.

Palley, T.I., The Economics of Inflation Targeting: Negatively Sloped, Vertical, and Backward-Bending Phillips Curves, manuscript, Washington DC, 2006.

------------, “The Backward Bending Phillips Curve and the Minimum Unemployment rate of Inflation (MURI): Wage Adjustment with Opportunistic Firms," The Manchester $\underline{\text { School of Economic and Social Studies, }} 71$ (1) (January 2003b), 35 - 50. 1998), 7 - 18 .

, "Zero is Not the Optimal Rate of Inflation," Challenge, 41 (January-February, -----------, "The Institutionalization of Deflationary Policy Bias," Monnaie et Production, Vol.X of Economies et Societes, 1996a, 247-68.

----------, Post Keynesian Economics: Debt, Distribution and the Macro Economy, Chapter 11. London: Macmillan, 1996 b.

-----------, "Growth Theory in a Keynesian Mode: Some Keynesian Foundations for New Endogenous Growth Theory", Journal of Post Keynesian Economics, 19 (Fall 1996c), 113-35.

-----------, “Investment, Profitability, and the Business Cycle: A Simple Model with Chaotic and Asymmetric Dynamics," unpublished, Department of Economics, New School for Social Research, 1995.

-----------, "Escalators and Elevators: A Phillips Curve for Keynesians," Scandinavian Journal of Economics, 96 (1), 1994.

Phelps, E.S., "Money Wage Dynamics and Labor Market Equilibrium," Journal of Political Economy, 76 (1968), $678-711$.

Poole, W., "Optimal Choice of Monetary Policy Instruments in a Simple Stochastic Macro Model,’ Quarterly Journal of Economics, 84 (1970), 197 - 216.

Sargent, T.J., and N.Wallace, "Rational Expectations, the Optimal Monetary Instrument, and the Optimal Money Supply Rule," Journal of Political Economy, 83 (1975), 241-54. 
Solow, R.M., "A Contribution to the Theory of Economic Growth," Quarterly Journal of Economics, 70 (1956), $65-94$.

Taylor, J.B., "Discretion versus Policy Rules in Practice," Carnegie - Rochester Conference Series on Public Policy, 39 (1993), 195 - 214.

Tobin, J., "Inflation and Unemployment," American Economic Review, 62 (1972), 1 26.

-----------, "Money and Economic Growth,” Econometrica, 33 (1965), 671 - 84. 


\section{Figure 1. The New Classical Model}

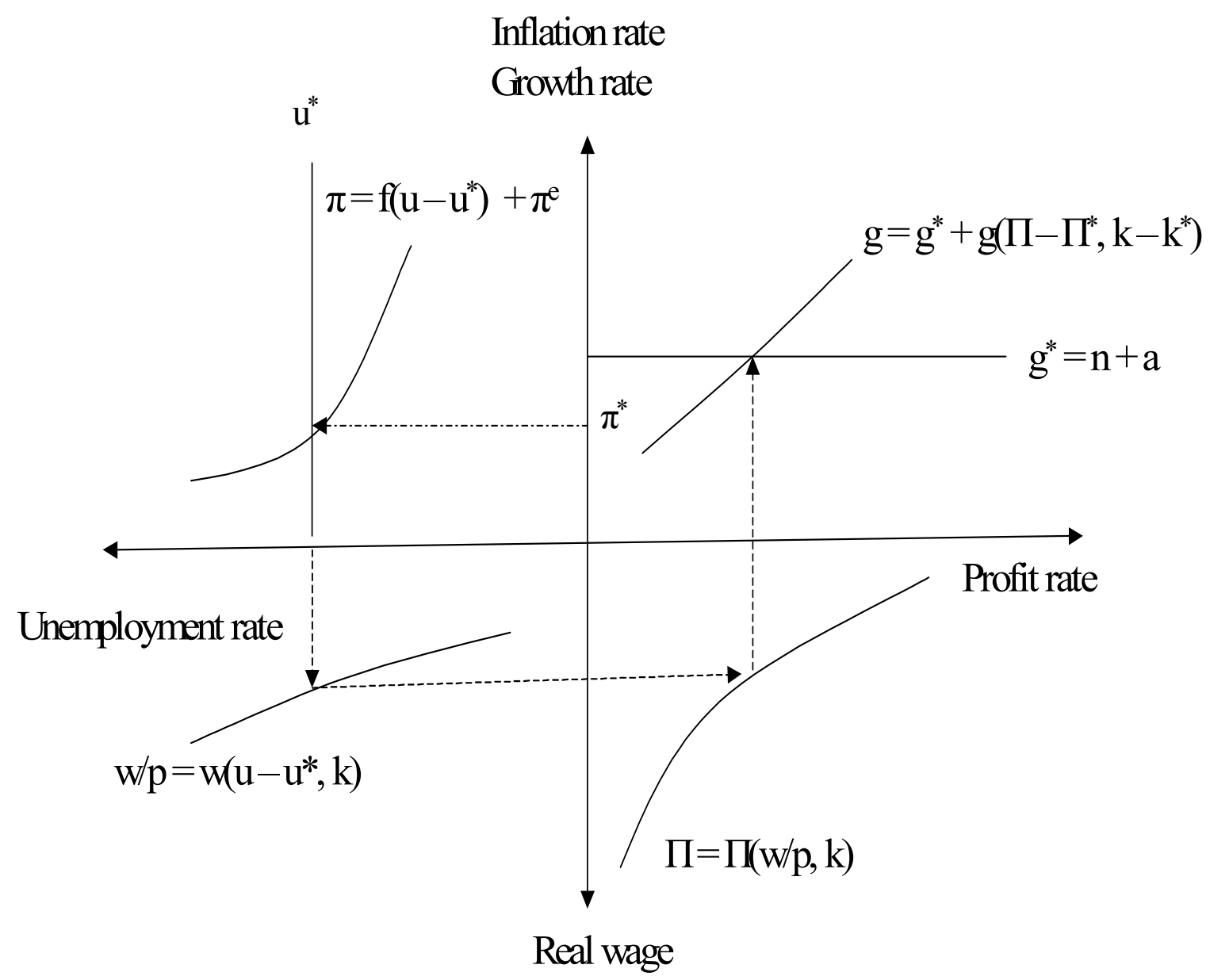




\section{Figure 2. The Post Keynesian Mbdel}

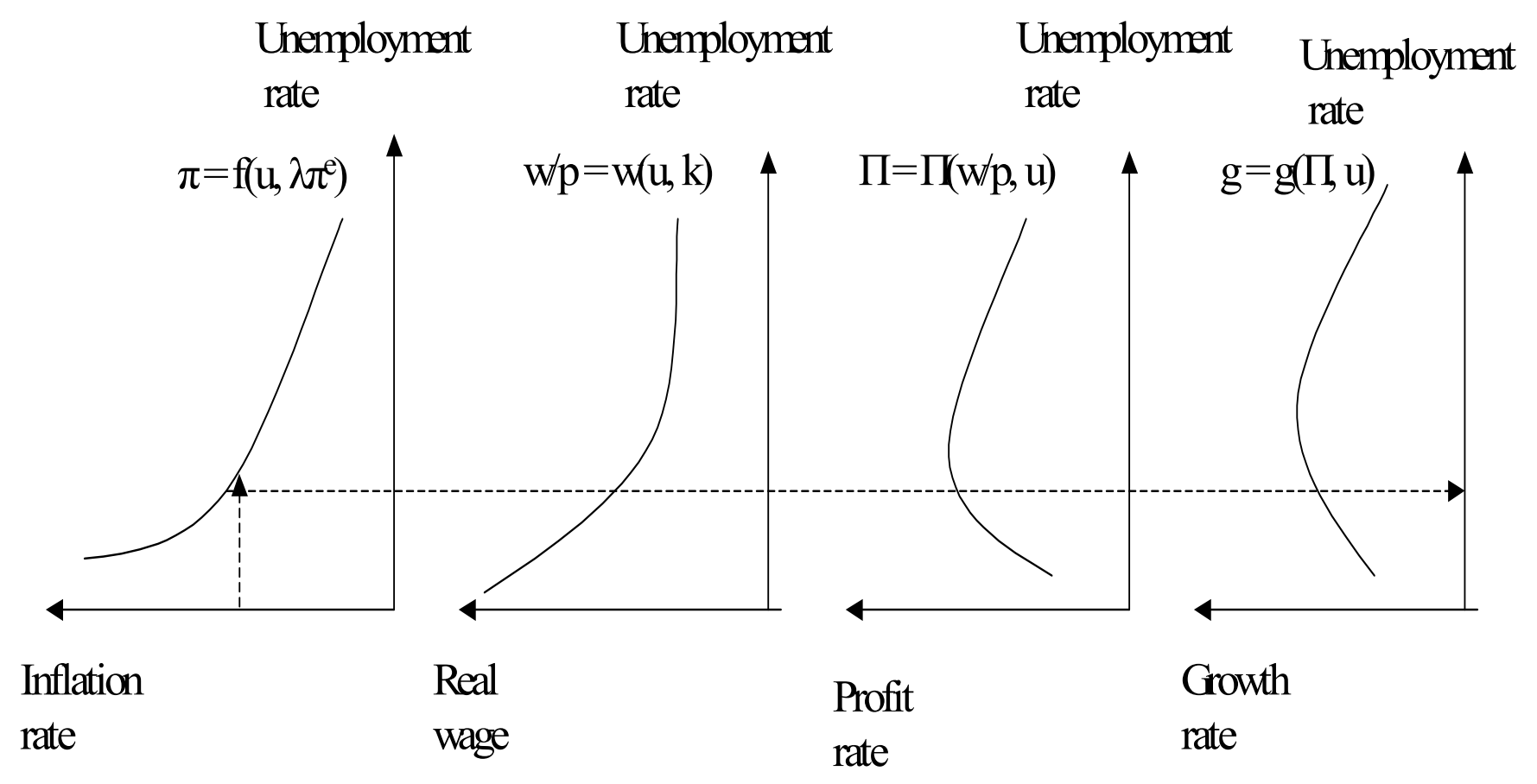




\section{Figure 3. The Post Keynesian Model with a backward-bending Phillips Curve}

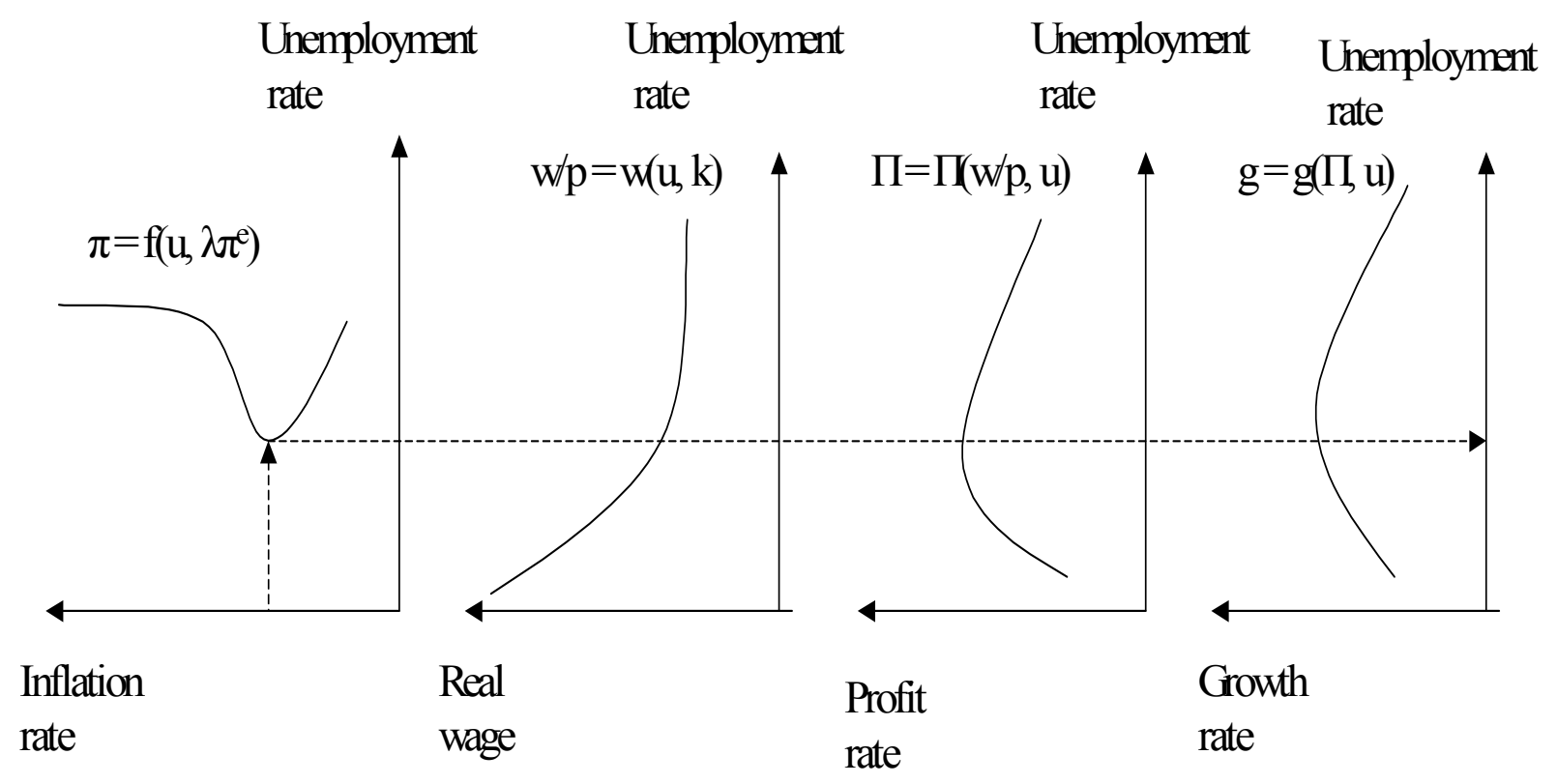

